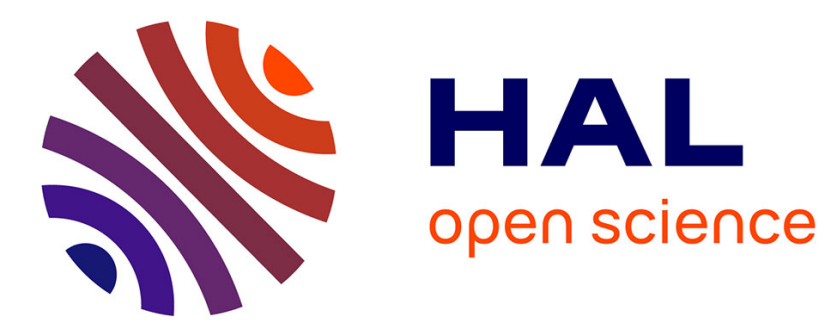

\title{
Synthesis and characterization of bis(bipyridine)ruthenium(II) complexes with bromo or protected ethynyl $\beta$-diketonato ligands
}

Sabrina Munery, Joël Jaud, Jacques Bonvoisin

\section{- To cite this version:}

Sabrina Munery, Joël Jaud, Jacques Bonvoisin. Synthesis and characterization of bis(bipyridine)ruthenium(II) complexes with bromo or protected ethynyl $\beta$-diketonato ligands. Inorganic Chemistry Communications, 2008, 11 (9), pp.975-977. 10.1016/j.inoche.2008.05.012 . hal-01737691

\section{HAL Id: hal-01737691 \\ https://hal.science/hal-01737691}

Submitted on 19 Mar 2018

HAL is a multi-disciplinary open access archive for the deposit and dissemination of scientific research documents, whether they are published or not. The documents may come from teaching and research institutions in France or abroad, or from public or private research centers.
L'archive ouverte pluridisciplinaire HAL, est destinée au dépôt et à la diffusion de documents scientifiques de niveau recherche, publiés ou non, émanant des établissements d'enseignement et de recherche français ou étrangers, des laboratoires publics ou privés. 
Synthesis and characterization of bis(bipyridine)ruthenium(II) complexes with bromo or protected ethynyl $\beta$-diketonato ligands.

Sabrina Munery, Joël Jaud, Jacques Bonvoisin*

NanoSciences Group, CNRS/CEMES/GNS, 29 rue Jeanne Marvig, BP 94347, 31055

Toulouse Cedex 4, France.

E-mail: jbonvoisin@cemes.fr

NanoSciences Group, CNRS/CEMES/GNS, 29 rue Jeanne Marvig, BP 94347, 31055

Toulouse Cedex 4, France. Tel:+33 562257852 ; fax: +33 562257999.

\begin{abstract}
A protected ethynyl group was introduced into a $\gamma$-position of a ( $\beta$ diketonato)bis(bipyridine)ruthenium(II) complex through the reaction of the bromo complex and (triisopropylsilyl)-acetylene with very good yield under microwave irradiation. Two new mononuclear mixed-ligand ruthenium(II) complexes with bipyridine (bpy) and functionalized acetylacetonate ion (2,4-pentanedionate, $\left.\mathrm{acac}^{-}\right), \quad\left[\mathrm{Ru}(\mathrm{bpd})(\mathrm{bpy})_{2}\right]\left(\mathrm{PF}_{6}\right) \quad\left(\mathbf{2} ;\right.$ bpy $=2,2^{\prime}-$ bipyridine, bpd = 3-Bromo-2,4-pentanedionate ion) and $\left[\mathrm{Ru}(\right.$ tipsepd $\left.)(\mathrm{bpy})_{2}\right]\left(\mathrm{PF}_{6}\right)(3$; tipsepd = 3-((Triisopropylsilyl)ethynil)-2,4-pentanedionate ion) were then prepared as candidates for building blocks. The ${ }^{1} \mathrm{H}$ NMR, UV-Vis, electrochemistry and FAB mass spectral data of these complexes are presented. X-Ray single crystal diffraction analysis has been made on complex 2, it crystallized with empirical formula of $\mathrm{C}_{25} \mathrm{H}_{22} \mathrm{BrF}_{6} \mathrm{~N}_{4} \mathrm{O}_{2} \mathrm{PRu}$, in a monoclinic crystal system and space group C $2 / \mathrm{c}$ with $\mathrm{a}=29.340(5) \AA, \mathrm{b}=13.282(2) \AA, \mathrm{c}=15.7492$ (14) $\AA$, $\beta=$ $109.452(8)^{\circ}, \mathrm{V}=5786.9(13) \AA^{3}$ and $\mathrm{Z}=8$.
\end{abstract}

Keywords: Ruthenium(II) bipyridyl complex; $\beta$-diketone complex; Acetylenic compounds; Mixed ligand; X-Ray structure; Microwave irradiation synthesis.

A terminal alkyne can form a bridging group between two metal atoms or organometallic moieties.[1-3] Hoshino et al have shown that the introduction of alkyne group 
at the $\gamma$-position of a $\beta$-diketonato chelate ring can lead to several oligomers or polymers with interesting properties. [1, 4-6]. Nevertheless the way they prepare their building blocks is long and tedious.[4] Here, we present a new way for preparing them using an easy and quick method. It consists on using the brominated precursor $\left[\mathrm{Ru}(\mathrm{bpd})(\mathrm{bpy})_{2}\right]\left(\mathrm{PF}_{6}\right) \mathbf{2}$ to get the ethynyl-protected product $\left[\mathrm{Ru}(\text { tipsepd)(bpy })_{2}\right]\left(\mathrm{PF}_{6}\right) \mathbf{3}$ by Sonogashira cross-coupling reaction under microwave irradiation (Scheme 1). As well as the synthetic work, ${ }^{1} \mathrm{H}$ NMR, UV-Vis, electrochemistry and FAB mass spectral data of these complexes are also described. In addition, X-Ray analysis of complex $\mathbf{2}$ is presented.

All chemicals and solvents were of reagent grade or better. $\mathrm{Ru}(\mathrm{bpy}) \mathrm{Cl}_{2}$ was prepared according to Coudret et al. [7] The complexes were purified by column chromatography using Silica gel 60 (Merck). Elemental analyses were performed by the 'Service de microanalyse ICSN-CNRS Gif/Yvette'. UV-Visible spectra were recorded on a Varian Cary 5000 spectrophotometer. Cyclic voltammograms were obtained with an Autolab system (PGSTAT100) in $\mathrm{CH}_{2} \mathrm{Cl}_{2}(0.1 \mathrm{M}$ tetrabutylammonium hexafluorophosphate, TBAH as supporting electrolyte) at $25^{\circ} \mathrm{C}$. A three electrode cell was used comprising a $1 \mathrm{~mm} \mathrm{Pt-disk}$ working electrode, a Pt wire auxiliary electrode, and an aqueous saturated calomel (SCE) reference electrode. Mass spectra were recorded by the 'Service de Spectroscopie de Masse' of Paul Sabatier University using FAB (Nermag R10-R10, NBA matrix) in positive mode. ${ }^{1} \mathrm{H}$ NMR spectra were taken on Brucker Avance $300 \mathrm{MHz}$ equipment in $\mathrm{CD}_{2} \mathrm{Cl}_{2}$. The microwave heating was carried out in closed vials with a CEM-Discover monomode microwave apparatus at 150 watts under the conditions (temperature, time) given here. After completion of the reaction, the vessel was cooled down rapidly to $60^{\circ} \mathrm{C}$. 
Scheme 1

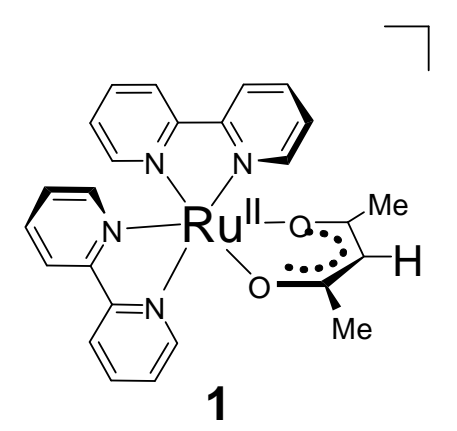

yield, $80 \%$
$\mathrm{PF}_{6}$

NBS

DCM, RT

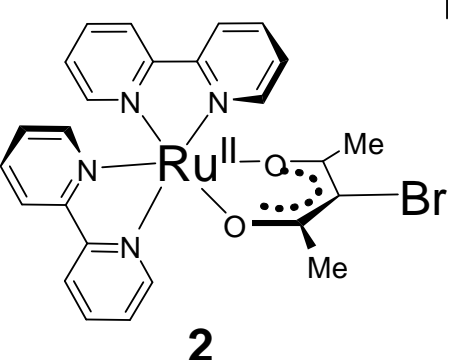

yield, $78 \%$

microwave, $1 \mathrm{~h}$

$100^{\circ} \mathrm{C}$

Cul - $\mathrm{Pd}\left(\mathrm{PPH}_{3}\right)_{2} \mathrm{Cl}_{2}$

$\mathrm{DMF} /$ piperidine

TIPSA

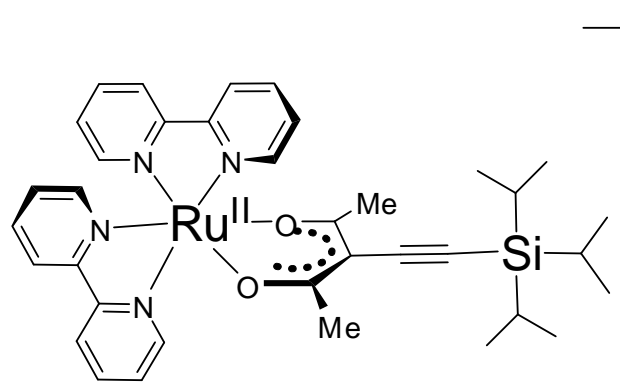

3

yield, $62 \%$

The synthesis of complexes $\mathbf{2}$ [9] and $\mathbf{3}$ [10] follows the procedure given in scheme 1 . $\left[\mathrm{Ru}(\mathrm{acac})(\mathrm{bpy})_{2}\right]\left(\mathrm{PF}_{6}\right)(\mathbf{1})$ [8] was prepared by the method of El-Hendawy et al. [12] No yield was given on this work, we got around 50\% yield. This was increased to $80 \%$ by adding tBuOK during the reaction. The bromination, an electrophilic substitution, occurred selectively at the $\gamma$-position of the acac ligand and led compound $\mathbf{2}$ with good yield (around $80 \%$ ); the synthesis was adapted from literature procedure. [4, 17] Hoshino et al reported a method for introducing an ethynyl group into a $\gamma$-position of tris( $\beta$-diketonato)ruthenium(III) complexes but this method is long ( 4-5 days) and give poor yield ( 40\%). [4] Compounds 3 was made here by using a much quicker method (1h) which gives pure compounds with higher yield (60\%), it was prepared by a Sonogashira cross-coupling reaction [18] between the Bromoruthenium complex 2 and triisopropylsilylacetylene (TIPSA) under classic conditions ( $\mathrm{CuI}, \mathrm{Pd}\left(\mathrm{PPH}_{3}\right)_{2} \mathrm{Cl}_{2}$, DMF/piperidine) but under microwave irradiation. Other 
examples of microwave-assisted synthesis of ruthenium(II) polypyridine complexes appeared recently in the literature. $[19,20]$

The ${ }^{1} \mathrm{H}$ NMR data for the complexes 1-3 are in accordance with the proposed structures illustrated in scheme 1. Note the absence of the proton at the $\gamma$-position for $\mathbf{2}$ and $\mathbf{3}$.

Table 1

UV-Visible and electrochemical data

\begin{tabular}{lll}
\hline Complex & $\begin{array}{l}\mathrm{UV}-\mathrm{Vis} \text { data } \\
\end{array}$ & $\begin{array}{l}\text { Redox potentials }^{\mathrm{b}} \\
\mathrm{E}_{1 / 2} / \mathrm{nm}(\varepsilon \mathrm{\textrm {E }}, \mathrm{V})\end{array}$ \\
\hline $\mathbf{1}$ & $247(25.7), 296(50), 373(10), 521(8), 564 \mathrm{sh}(5.5)$ & $+0.678(0.074)$ \\
$\mathbf{2}$ & $247(22), 296(51), 370(11), 511(8), 559 \mathrm{sh}(5.7)$ & $+0.752(0.070)$ \\
$\mathbf{3}$ & $248(35.6), 297(55.7), 370(12.9), 511(9), 556 \mathrm{sh}(6.4)$ & $+0.743(0.071)$ \\
\hline
\end{tabular}

${ }^{\mathrm{a}} \mathrm{In} \mathrm{CH}_{2} \mathrm{Cl}_{2}$

${ }^{\mathrm{b}}$ Versus SCE, in $\mathrm{CH}_{2} \mathrm{Cl}_{2}, 0.1 \mathrm{M}$ TBAH, $0.1 \mathrm{~V} / \mathrm{s}$

Cyclic voltammetry (CV) data for the complexes is given in Table 1. The $\mathrm{E}_{1 / 2}$ potentials were determined from the average of the anodic and cathodic peak potentials. All the waves are reversible with peak to peak separation of around $70-75 \mathrm{mV}$. The reversible half-wave potentials $E_{1 / 2}$ of $\mathbf{2 - 3}$ are $74-65 \mathrm{mV}$ more positive than that of 1.These positive shifts of the potentials reflects the electron-withdrawing character of $-\mathrm{Br}$ and $\mathrm{C} \equiv \mathrm{CSi}\left(\mathrm{CHMe}_{2}\right)_{3}$. A similar positive shift was observed in the case of Tris $(\beta$ diketonato)ruthenium(III) compounds as well.[4] 


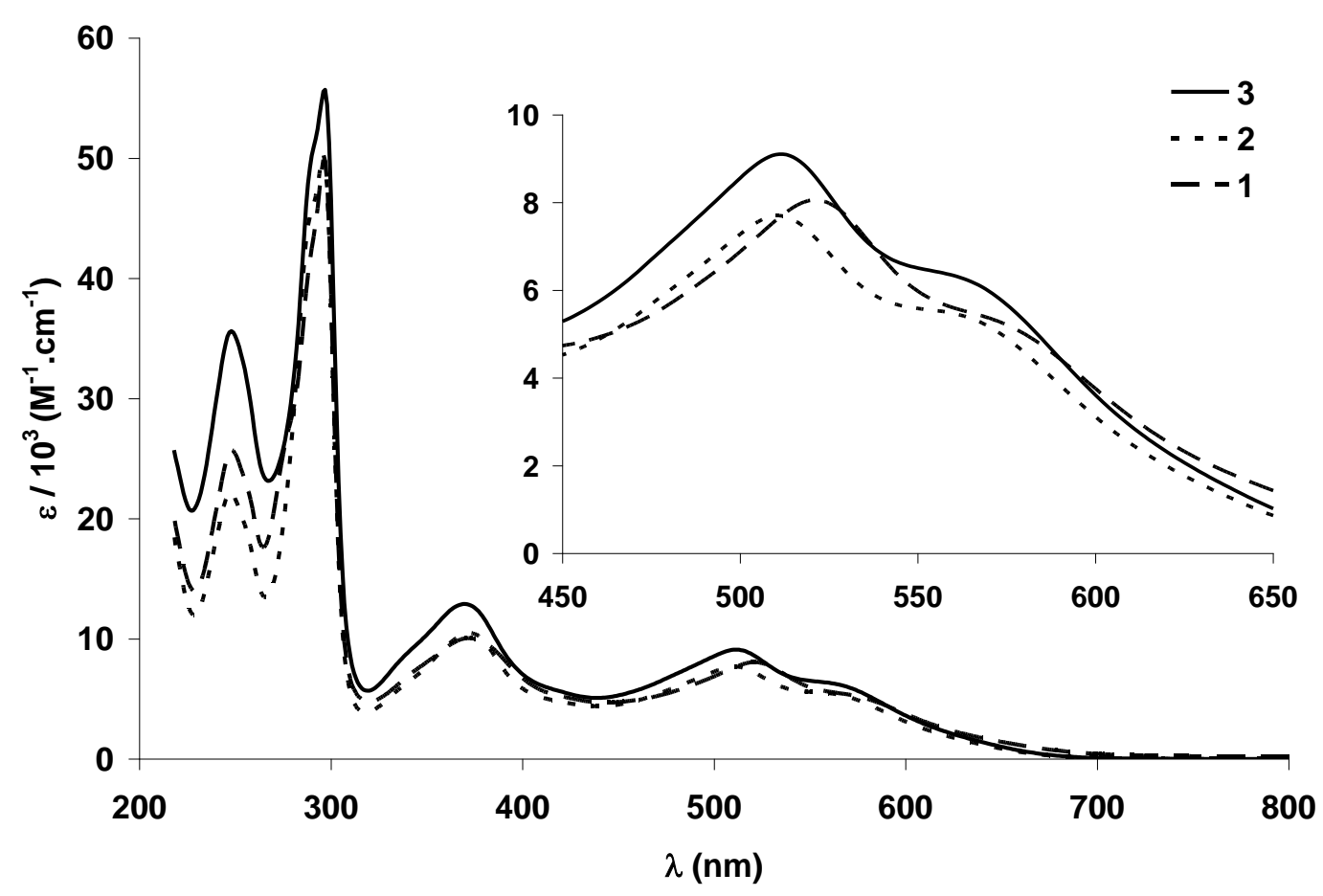

Figure 1. UV-Vis Spectra of complexes 1, 2 and $\mathbf{3}$ in $\mathrm{CH}_{2} \mathrm{Cl}_{2}$. Insert: Enlargement of the specified area.

The UV-Vis data are shown in Table 1 and Figure 1. The overall shape of the absorption bands for the three compounds look like the same, they show two bands in the UV region, probably attributed to $\pi \rightarrow \pi^{*}$ intra ligand (IL), and three metal-to-ligand charge transfert transitions (MLCT) in the visible with large molar extinction coefficient values as similarly observed for mixed-ligand $\mathrm{Ru}(\mathrm{II})$ complexes with bpy and $\beta$-diketonato type ligands. [8, 21-23] Nevertheless two points can be noted: - The band at 521nm from 1 follows a blue shift to $511 \mathrm{~nm}$ for both $\mathbf{2}$ and $\mathbf{3}$ (See insert on Figure 1). - A hyperchromic effect is observed for the absorption band located at 248nm going from 1-2 to 3, probably due to the $\mathrm{C} \equiv \mathrm{C}$ triple bond appearing in $\mathbf{3}$.

The ORTEP diagram of complex $\mathbf{2}$ is shown in Figure 2. The hexafluorophosphate counter anion was omitted for the sake of clarity. Crystallographic data and selected bond lengths and angles are shown on Supplementary material (Table S1 and S2). The sixcoordinated ruthenium atom is chelated by the two bipyridines and by the bromoacetyacetonate ligand. The Ru-N distances as well as the bond angles are consistent within the ranges of values reported in the literature. [24-26] 


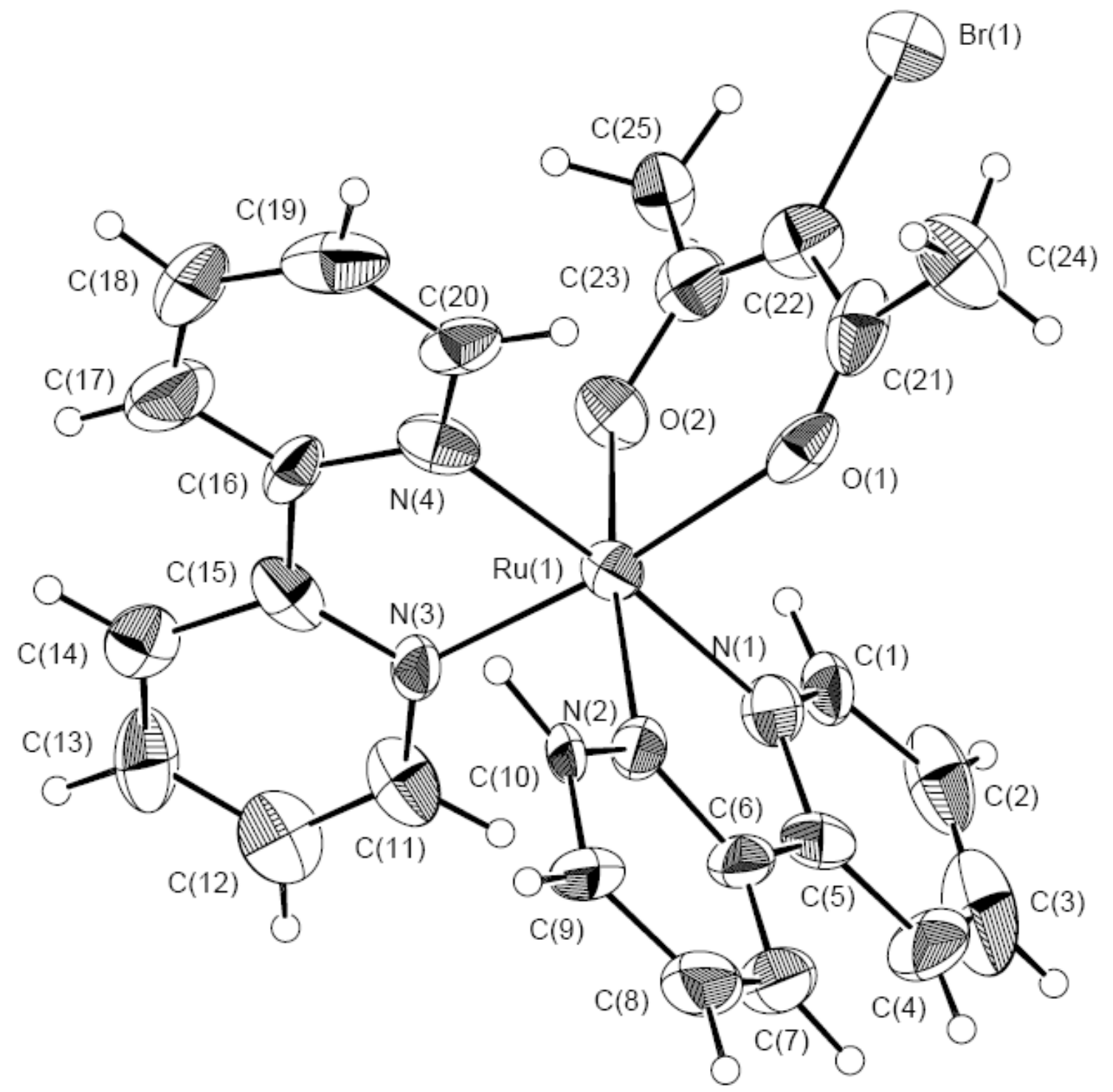

Figure 2. ORTEP drawing of $\left[\mathrm{Ru}(\mathrm{bpd})(\mathrm{bpy})_{2}\right]^{+} \mathbf{2}$ complex cation (probability level of $30 \%)$.

In conclusion, we have shown that the introduction of a protected-ethynyl group into a $\gamma$-position of a $\beta$-diketonato chelate ring can be made in a very efficient and quick procedure, compared to prior experiments using microwave irradiation in order to get compound 3. Once deprotected, this compound will be used in the future for molecular electronics application. It can be seen as potential candidate for the preparation of functional single-molecule devices. 


\section{Supplementary material}

Crystallographic data and refinement parameters (Table S1) and selected bond lengths ( $\AA$ ) and bond angles $\left(^{\circ}\right)\left(\right.$ Table S2) for $\left[\mathrm{Ru}(\mathrm{bpd})(\mathrm{bpy})_{2}\right]\left(\mathrm{PF}_{6}\right)$ 2. CCDC 676887 contains the supplementary crystallographic data for this paper. These data can be obtained free of charge via www.ccdc.cam.ac.uk/data request/cif , by emailing data request@ecdc.cam.ac.uk, or by contacting The Cambridge Crystallographic Data Centre, 12, Union Road, Cambridge CB2 1EZ, UK; fax: +44 1223336033.

\section{Acknowledgements}

The authors thank CNRS for financial support, Christine Viala (CEMES) for technical assistance.

\section{References}

[1] Y. Hoshino, S. Higuchi, J. Fiedler, C. Y. Su, A. Knodler, B. Schwederski, B. Sarkar, H. Hartmann, and W. Kaim, Angew. Chem. Int. Ed. 42 (2003) 674.

[2] F. Paul and C. Lapinte, Coord. Chem. Rev. 180 (1998) 431.

[3] N. J. Long and C. K. Williams, Angew. Chem. Int. Ed. 42 (2003) 2586.

[4] Y. Kasahara, Y. Hoshino, M. Kajitani, K. Shimizu, and G. P. Sato, Organometallics 11 (1992) 1968.

[5] Y. Hoshino and Y. Hagihara, Inorg. Chim. Acta 292 (1999) 64.

[6] Y. Hoshino, Platinum Metals Rev. 45 (2001) 2.

[7] C. Viala and C. Coudret, Inorg. Chim. Acta 359 (2006) 984.

[8] Preparation of $\left[\mathrm{Ru}(\mathrm{acac})(\mathrm{bpy})_{2}\right](\mathrm{PF} 6)(\mathbf{1}$; acac $=2,4$-pentanedionate ion) 1 was prepared via a slightly modified procedure given by El-Hendawy et al.[12] Dark red powder was obtained. Yield: $51 \%$. The yield was increased to $80 \%$ by adding stoechiometric quantity of potassium tert-butoxide (tBuOK). ${ }^{1} \mathrm{H} \mathrm{NMR}\left(\mathrm{CD}_{2} \mathrm{Cl}_{2} \delta=\right.$ 5.35): $8.73(2 \mathrm{H}, \mathrm{ddd}, 0.8,1.5,5.6 \mathrm{~Hz}) 8.37(2 \mathrm{H}, \mathrm{d}, 8,1 \mathrm{~Hz}) 8.24(2 \mathrm{H}, \mathrm{d}, 8 \mathrm{~Hz}) 8.08$ $(2 \mathrm{H}, \mathrm{m}) 7.74(4 \mathrm{H}, \mathrm{m}) 7.63(2 \mathrm{H}, \mathrm{ddd}, 1.3,5.6,7.5 \mathrm{~Hz}) 7.12(2 \mathrm{H}, \mathrm{ddd}, 1.4,5.7,7.3 \mathrm{~Hz})$ $5.40(1 \mathrm{H}, \mathrm{s}, \gamma-\mathrm{CH}) 1.86(6 \mathrm{H}, \mathrm{s}) . \mathrm{CV}\left(\mathrm{DCM}, 0.1 \mathrm{M} \mathrm{TBAH}, 0.1 \mathrm{~V} \mathrm{~s}^{-1}\right.$, vs SCE) $\mathrm{E}_{1 / 2}\left(\mathrm{Ru}^{\mathrm{II}} / \mathrm{Ru}^{\mathrm{III}}\right)=0.68 \mathrm{~V}, \Delta \mathrm{E}=0.074 \mathrm{~V}$.

[9] Preparation of $\left[\mathrm{Ru}(\mathrm{bpd})(\mathrm{bpy})_{2}\right]\left(\mathrm{PF}_{6}\right)(\mathbf{2} ; \mathrm{bpd}=3$-Bromo-2,4-pentanedionate ion) 2 was obtained by the direct substitution of the 3-position of the acac ligand of $\mathbf{1}$. NBromosuccinimide (NBS) $(0.14 \mathrm{~g}, 0.80 \mathrm{mmol})$ was added to a dichloromethane (DCM) solution $(100 \mathrm{~mL})$ of $1(0.50 \mathrm{~g}, 0.76 \mathrm{mmol})$. After stirring at room temperature under argon for $1 \mathrm{~h}, \mathrm{NH}_{4} \mathrm{PF}_{6}(0.02 \mathrm{~g}, 0.123 \mathrm{mmol})$ was added. After evaporation of the solvent, the complex was purified using column chromatography on Silica with a mixture of $\mathrm{CH}_{2} \mathrm{Cl}_{2} / \mathrm{CH}_{3} \mathrm{CN}$ (90:10). A black red solid was obtained after evaporation to dryness $(0.44 \mathrm{~g}, 78 \%)$. IR $v / \mathrm{cm}^{-1} 842 \mathrm{~s}\left(\mathrm{PF}_{6}\right) .{ }^{1} \mathrm{H} \mathrm{NMR}\left(\mathrm{CD}_{2} \mathrm{Cl}_{2} \delta=5.35\right) 8.71(2 \mathrm{H}$, ddd, $0.8,1.5,5.6 \mathrm{~Hz}) 8.39(2 \mathrm{H}, \mathrm{d}, 8.1 \mathrm{~Hz}) 8.26(2 \mathrm{H}, \mathrm{d}, 8 \mathrm{~Hz}) 8.16(2 \mathrm{H}, \mathrm{m}) 7.78(2 \mathrm{H}$, m) $7.66(4 \mathrm{H}, \mathrm{m}) 7.13(2 \mathrm{H}$, ddd, 1.4. 5.7, 7.3 Hz) $2.23(6 \mathrm{H}, \mathrm{s})$. FAB Mass spectrum (DCM) m/z: 591 [M-PF $]^{+}$(calcd 591.4). Anal. Calcd. (\%) for $\mathrm{C}_{25} \mathrm{H}_{22} \mathrm{BrF}_{6} \mathrm{~N}_{4} \mathrm{O}_{2} \mathrm{PRu}$ : C, 40.8; H, 3.0; N, 7.6. Found: C, 40.0; H, 3.0; N, 7.0 CV (DCM, 0.1M TBAH, 0.1Vs ${ }^{1}$, vs SCE) $\mathrm{E}_{1 / 2}\left(\mathrm{Ru}^{\mathrm{II}} / \mathrm{Ru}^{\mathrm{III}}\right)=0.75 \mathrm{~V}, \Delta \mathrm{E}=0.073 \mathrm{~V}$. 
[10] Preparation of [Ru(tipsepd)(bpy $\left.)_{2}\right]\left(\mathrm{PF}_{6}\right)(\mathbf{3}$; tipsepd = 3-((Triisopropylsilyl)ethynil)2,4-pentanedionate ion). [Ru(bpy) $\left.{ }_{2} \mathrm{bpd}\right](\mathrm{PF} 6) 2$ (0.10g, 1.36mmol), CuI (0.01g, $0.06 \mathrm{mmol}), \mathrm{Pd}\left(\mathrm{PPH}_{3}\right)_{2} \mathrm{Cl}_{2}(0.01 \mathrm{~g}, 0.02 \mathrm{mmol})$ were placed in a solution in the solvent mixture $\mathrm{DMF} /$ piperidine $(2: 1,3 \mathrm{~mL})$ previously degassed with argon.

Triisopropylsilylacetylene $(3 \mathrm{~mL}, 1.34 \mathrm{mmol})$ was added under argon. The reaction mixture was stirred at $100^{\circ} \mathrm{C}$ under microwave irradiation $(150 \mathrm{w})$ for $1 \mathrm{~h}\left(\mathrm{P}_{\max }: 10\right.$ bars). After reaction, TLC plate shows only one spot which reveals the end of the reaction and the purity of the product. The solution was evaporated to dryness. The crude product was purified by column chromatography on Silica with a mixture of $\mathrm{CH}_{2} \mathrm{Cl}_{2} / \mathrm{CH}_{3} \mathrm{CN}$ (90:10) to give a dark red powder of 3. $(0.07 \mathrm{~g}, 62 \%)$. IR v/cm ${ }^{-1} 2137 \mathrm{~s}$ $(\mathrm{C} \equiv \mathrm{C})$ and $842 \mathrm{~s}\left(\mathrm{PF}_{6}\right) .{ }^{1} \mathrm{H}$ NMR $\left(\mathrm{CD}_{2} \mathrm{Cl}_{2} \delta=5.35\right) 8.70(2 \mathrm{H}, \mathrm{ddd}, 0.7,1.4,5.6 \mathrm{~Hz})$ $8.38(2 \mathrm{H}, \mathrm{d} 8.1 \mathrm{~Hz}) 8.25(2 \mathrm{H}, \mathrm{d}, 8.0 \mathrm{~Hz}) 8.11(2 \mathrm{H}, \mathrm{dt}, 1.5,7.9 \mathrm{~Hz}) 7.78(2 \mathrm{H}, \mathrm{m}) 7.68$ $(4 \mathrm{H}, \mathrm{m}) 7.13(2 \mathrm{H}, \mathrm{ddd}, 1.4,5.8,7.3 \mathrm{~Hz}) 2.22(6 \mathrm{H}, \mathrm{s}) 1.1(21 \mathrm{H}, \mathrm{s}$, TIPS). FAB Mass

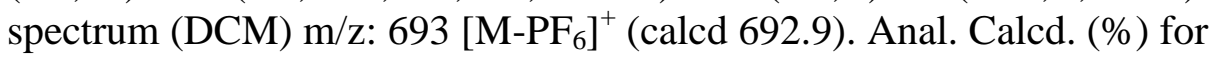
$\mathrm{C}_{36} \mathrm{H}_{43} \mathrm{~F}_{6} \mathrm{~N}_{4} \mathrm{O}_{2} \mathrm{PRuSi}$ : C, 51.6; H, 5.2; N, 6.7. Found: C, 50.9; H, 5.1; N, 6.3. CV (DCM, 0.1M TBAH, $0.1 \mathrm{Vs}^{-1}$, vs SCE) $\mathrm{E}_{1 / 2}\left(\mathrm{Ru}^{\mathrm{II}} / \mathrm{Ru}^{\mathrm{III}}\right)=0.74 \mathrm{~V}, \Delta \mathrm{E}=0.071 \mathrm{~V}$.

[11] Dark red parallelepiped crystals of $\left[\mathrm{Ru}(\mathrm{bpd})(\mathrm{bpy})_{2}\right]\left(\mathrm{PF}_{6}\right) 2$ were grown by slow evaporation of a mixture of a toluene/acetonitrile solution of the complex. A summary of crystal data is given in Table 1 . The selected crystal for the measurement was a small plate with the following size $0.13 ; 0.50$ and $0.50 \mathrm{~mm}$. The crystals were of poor quality. First measurement at room temperature reveals big disorder around the PF6anions. The compound crystallizes in monoclinic system with the $\mathrm{C} 2 / \mathrm{c}$ space group. Temperature of data collection was temptatively dropped lower than $150 \mathrm{~K}$ but the crystal did not resist and broke. The diffraction intensities were then collected on a Nonius Kappa CCD diffractometer at $150 \mathrm{~K}$ using graphite monochromated Mo- $K_{\alpha}$ radiation $(\lambda=0.71073 \AA)$ equipped with an APEXII two-dimensional detector. Images treatments were done by using EVAL-CCD [13] and the collected hkl treated by the maXus software package. [14] The structure was solved using DIRDIF. [15] At this point, the $\mathrm{C}_{25} \mathrm{H}_{22} \mathrm{BrN}_{4} \mathrm{O}_{2} \mathrm{Ru}$ entity and the phosphorus atom appeared rather easily but the position of the fluorine atoms were very difficult to locate even at low temperature (150K). The structure was then refined using SHELX. [16] The refinement was performed anisotropically for all the non-hydrogen atoms of the complex except for the fluorine atoms. About the fluorine atoms, partial occupations were introduced and constraints on P-F lengths were imposed. In spite of the disorder, the hydrogen atoms could be localized by difference Fourier functions, recalculated and fixed at $0.96 \AA$ from the corresponding carbon atoms with an isotropic thermal agitation proportional to the one of the linked carbon atoms. In spite of the poor quality of the $\mathrm{R}$ value due to the disorder and the poor crystallinity of the sample, the geometry of the studied compound could be described without ambiguities.

[12] A. M. El-Hendawy, A. H. Al-Kubaisi, and H. A. Al-Madfa, Polyhedron 16 (1997) 3039.

[13] A. J. M. Duisenberg, Reflections on Area Detectors, Utrecht, 1998

[14] S. Mackay, C. J. Gilmore, C. Edwards, N. Stewart, and K. Shankland, maXus Computer Program for the Solution and Refinement of Crystal Structures, Nonius, The Netherlands, MacScience \& the University of Glasgow, the Netherlands/Japan, 1999

[15] P. T. Beurskens, G. Beurskens, R. de Gelder, S. Garcia-Granda, R. O. Gould, R. Israel, and J. M. M. Smits, The DIRDIF-99 program system, University of Nijmegen, The Netherlands, 1999

[16] G. M. Sheldrick, University of Göttingen, Germany, 1997.

[17] A. Endo, K. Shimizu, G. P. Sato, and M. Mukaida, Chem. Lett. (1984) 437. 
[18] K. Sonogashira, Y. Tohda, and N. Hagihara, Tetrahedron Lett. 50 (1975) 4467.

[19] H. J. Bolink, L. Cappelli, E. Coronado, M. Gratzel, and M. K. Nazeeruddin, J. Am. Chem. Soc. 128 (2006) 46.

[20] X. M. Xiao, J. Sakamoto, M. Tanabe, S. Yamazaki, S. Yamabe, and T. MatsumuraInoue, J. Electroanal. Chem. 527 (2002) 33.

[21] J. Chakravarty and S. Bhattacharya, Polyhedron 15 (1996) 1047.

[22] Y. Takahashi, H. Arakawa, H. Sugihara, K. Hara, A. Islam, R. Katoh, Y. Tachibana, and M. Yanagida, Inorg. Chim. Acta 310 (2000) 169.

[23] S. C. Brooks, D. J. Vinyard, and M. M. Richter, Inorg. Chim. Acta 359 (2006) 4635.

[24] M. G. Sauaia, E. Tfouni, R. H. D. Santos, M. T. D. Gambardella, M. Del Lama, L. F. Guimaraes, and R. S. da Silva, Inorg. Chem. Comm. 6 (2003) 864.

[25] A. Baker, J. Jaud, J. P. Launay, and J. Bonvoisin, Inorg. Chim. Acta 358 (2005) 3513.

[26] M. Du, X. J. Ge, H. Liu, and X. H. Bu, J. Mol. Struct. 610 (2002) 207. 